\title{
Path creation as a process of resource alignment and anchoring - Industry formation for on-site water recycling in Beijing
}

\author{
Christian Binz, Bernhard Truffer, Lars Coenen
}

\begin{abstract}
Where and how new industrial paths emerge are much debated questions in economic geography, especially in light of the recent evolutionary turn. This paper contributes to the on-going debate on path creation with a new analytical framework that specifies the formation of 'generic resources' in embryonic industries. It suggests that path creation processes are not only conditioned by pre-existing regional capabilities and technological relatedness, but also by the way firm and non-firm actors mobilize and anchor key resources for industry formation. Our framework elaborates on the early industry development phase, extending the focus on regional knowledge spill-overs in evolutionary economic geography literature with recent insights on industry formation dynamics from innovation studies. It understands early path creation as conditioned by four systemic resource formation processes - knowledge creation, investment mobilization, market formation and technology legitimation - that can be mobilized both from inside or anchored from outside the region. The use and value of the analytical framework is illustrated by a case study on on-site water recycling technology, based on interviews with 40 experts in three Chinese city regions. The findings suggest that, despite possessing the least favourable initial conditions, a sizable on-site water recycling industry developed only in Beijing. This is explained based on the specific anchoring process of the four key resources in the early development stage of the industry. Our results imply that evolutionary economic geography would profit from incorporating a broader set of variables than knowledge-based relatedness in explanations of regional industrial path creation.
\end{abstract}

Keywords: evolutionary economic geography; path creation; resources; anchoring; technological innovation system; water recycling

Binz, C., Truffer, B., \& Coenen, L. (2016). Path creation as a process of resource alignment and anchoring: industry formation for on-site water recycling in Beijing. Economic Geography, 92(2), 172-200. https://doi.org/10.1080/00130095.2015.1103177 


\section{Introduction}

In the wake of an evolutionary turn, economic geography has witnessed lively debates on path dependency and the determinants of regional path creation (Boschma and Frenken 2006; Boschma and Martin 2010; Essletzbichler and Rigby 2007; Martin and Sunley 2006). In particular, the fundamental question where and how new industries emerge has regained interest in the relevant theoretical debates (Martin 2012; Martin 2011; Martin 2010; Simmie 2012b). Recent evolutionary studies strongly emphasize technological relatedness across regional industries, combinatorial knowledge dynamics and branching processes as key explanatory factors for where and how new industries develop (Asheim, et al. 2011; Neffke, et al. 2011; Boschma and Frenken 2011a). Regions are assumed to branch into technologically related fields in a path-dependent related diversification processes (Martin 2012; Neffke, et al. 2011; Cooke 2004; Boschma and Frenken 2011b). Where new industries emerge is strongly contingent (though not pre-determined) on the pre-existing industrial structure of regions.

This broad body of literature has shed new light on how and why 'history matters' for innovation and regional economic growth (Martin 2010). Yet, its conceptual and methodological approach has recently also attracted several lines of criticism (Hassink, et al. 2014; Henning, et al. 2013; Dawley 2014; MacKinnon, et al. 2009), two of which will be taken up in this paper: First, evolutionary economic geography’s focus on technological relatedness downplays the influence of non-firm actors, institutions and public policy in creating and/or renewing industrial development paths in a region (Hassink, et al. 2014; Dawley 2014; Asheim, et al. 2013). By emphasizing organizational routines at the firm level and knowledge spillovers through spin-offs, labor mobility, social networking or firm diversification, it tends to give partial accounts of the industry formation process which focuses rather exclusively on knowledge dynamics and black-boxes the collective action of firm and non-firm actors to create and exploit innovative opportunities in a region (Morgan, 2009; Coenen et al., 2015; MacKinnon et al., 2009; Simmie, 2012; Dawley 2014; Tanner 2014). Second, by emphasizing 'generic resources' (mostly sector-specific knowledge and skills) originating and evolving predominantly from inside the region, it risks incorporating a kind of 'regional fetishism' (Martin and Sunley 2006). As Asheim et al. $(2013,5)$ put it, in its current form, evolutionary economic geography is downplaying that "global innovation network linkages in their various forms can contribute to the renewal, extension or even 
transformation of the regional resource base” and - as we argue - the development of new industrial paths.

To address these critiques and to help further specify the generic resources involved in early path creation, this paper proposes a new analytical framework that explicitly includes firm and non-firm actors, key resource formation and alignment processes (beyond knowledge dynamics) and in particular the decisive role of extra-regional network connections in inducing new paths. We propose to conceptualize early path creation in relation to recent analytical frameworks from innovation studies and the literature on socio-technical transitions, two fields that have extensively analyzed the early industry formation phase. Drawing on their insights, path creation is conceptualized as a socio-technical alignment process in which heterogeneous actor networks mobilize not only knowledge, but also financial investment, market access and technology legitimacy from both inside and outside the region. In order to account for the changing geographies of innovation in a globalizing knowledge-based economy, we argue that it is crucial to understand how extra-regional resources influence the formation of specific regional growth paths and how resource formation and alignment processes get embedded in regional institutional contexts (Coenen, et al. 2012). 'Anchoring' of extra-regional resources (Crevoisier and Jeannerat 2009) is thus integrated as an integral part of explanations of early path creation.

By developing this analytical framework, the paper aims at generating more nuanced answers to the fundamental questions when (under what conditions) and how (through what kind of mechanisms) new industrial paths are created in regions (Boschma and Martin 2010; Dawley 2014; Tanner 2014). It hypothesizes that endogenous development factors - like pre-existing capabilities and technological relatedness - induce new paths only if they get integrated in a broader resource formation and alignment process in the global innovation system emerging around a new technology. In particular the coupling between (spatially extensive) technologyspecific actor networks and institutions and the actors embedded in a given regional innovation system are key to understanding how and where new industries form (Oinas and Malecki 2002).

In order to illustrate the use and value of the framework, we chose a case of an emerging industry in the field of urban infrastructure technology, namely on-site water recycling technology (OST) in China. Innovation success in this case does not only depend on adequate 
knowledge production, but requires the involvement of a broad array of actors and alignment with manifold institutional structures. This sort of institutionally complex case is well suited to develop our analytical framework that includes additional explanatory dimensions to knowledge and technology relatedness. Yet, in the discussion we will argue that the conceptual framework derived from this extreme case is of relevance beyond this single case also for path creation processes in other industries that rely more strongly on the generation of new knowledge stocks. The empirical analysis shows that Beijing was the only Chinese region that successfully created an embryonic path in this industry. Its success is remarkable, given that the region provided relatively unfavorable initial conditions. Two other regions, Xi' an and Shanghai, provided more promising generic resources with regard to technological relatedness, but both failed to create an OST industry. Comparing Beijing’s success case with two unsuccessful examples will illustrate the contributions of our framework to purely knowledge and relatedness-based explanations of path creation.

The remainder of the paper is structured as follows. The next section reviews the current debate in economic geography on (regional) path creation and identifies gaps in its conceptualization of the early path creation phase. Section 3 introduces elements from sociotechnical transition and technological innovation system literatures for an analytical framework that is based on resources, alignment processes and anchoring. The consecutive two sections present dataset and methodology and apply the framework to the emerging OST industry in Beijing, Xi'an and Shanghai. The conclusions further elaborate how the proposed framework adds new elements evolutionary economic geography’s path creation concepts.

\section{Path creation in evolutionary economic geography}

Over the last two decades, path dependency and organizational routines have become two key building blocks in evolutionary economic geography's theorizing of industrial path creation (Boschma and Frenken 2006; Martin 2010; Grabher 2009; Boschma and Frenken 2011c). In contrast to institutional and neoclassical approaches, evolutionary economic geography (EEG) understands path creation as a branching process out of a region's pre-existing industrial structure and organizational routines (Boschma and Frenken 2006; Boschma and Frenken 2011b; Trippl and Tödtling 2007). Similar to evolutionary economics, it starts from the 
assumption that firms consist of bundles of organizational routines, ${ }^{1}$ which get replicated and altered in a path-dependent process over time (Nelson and Winter 1982): As new technological or market opportunities emerge, new firms, spin-offs or subsidiaries of existing firms get created that try to exploit these new opportunities. These new organizations inherit the organizational routines from their predecessors and recombine them with related routines needed to exploit the product innovation (Nelson and Winter 1982). Over time, market competition acts as a selection environment that only lets firms with the most successful routines survive (Boschma and Frenken 2006). Empirical research shows that routine replication and recombination have a strong regional bias: Spin-offs often locate close to their parent organization (Klepper 1996), tacit knowledge spillovers occur more often among geographically proximate actors (Breschi and Lissoni 2001) and labor mobility is often constraint to a given labor market area (Frenken and Boschma 2007). Overall, in EEGs view, regional spillovers from related, yet not too proximate industries endogenously induce new industries in a region through processes of re-combinatorial innovation (Neffke, et al. 2011; Boschma and Frenken 2011b).

The merits of this approach in assessing the determinants of regional development have been widely demonstrated in a quickly growing body of literature (Boschma and Frenken 2006; Neffke, et al. 2011; Boschma and Frenken 2011b). Several empirical studies have shown that regions tend to branch into technologically related fields and that related and unrelated variety in their structural composition have positive effects on regional development and employment (Frenken, et al. 2007; Boschma, et al. 2012). Yet, whereas this perspective has proven useful in assessing the long-term, incremental evolution of regional industrial compositions, it has more problems in explaining why new paths typically emerge only in a few specific regions while they fail in others that provide equal (or even better) initial technological relatedness and organizational routines.

This limit of explanatory power in our view stems from gaps in EEG's conceptualization of the very early stages of new path creation (Martin 2010); the early phases of radically new paths are characterized as ‘windows of locational opportunity’ (Storper and Walker 1989; Boschma 1997; Scott and Storper 1987). As early industries rely on generic resources that are spread more or less ubiquitously in space, many regions have the same initial potential of

\footnotetext{
${ }^{1}$ Organizational routines consist mostly of (learning-by-doing) experience-based knowledge and tacit knowledge
} 
hosting them (Boschma 1997). First companies of a new industry thus locate randomly in one or several regions. Later, when companies have constructed a supportive context in specific regions, the new industry gets locked-in to a path-dependent development trajectory in specific places or regions (Storper and Walker 1989). In this perspective, historical accidents and the spatial distribution of 'generic resources', 'capabilities' or 'assets' explains early company's locational decisions, whereas the later probability of regions for developing a new industrial paths depends on the emerging sector’s interventions in the regional institutional contexts and supplier networks (Boschma 1997; Storper and Walker 1989; Boschma and Frenken 2009).

The process through which actors in a new technological field transform generic resources to new industries or induce regional industrial paths that deviate from existing trajectories is not conceptualized in much detail. Also the set of resources that the actors might draw on in the early path creation are not further specified. E.g. Hidalgo et al. (2007) talk broadly about ‘capabilities' (comprising mostly physical infrastructure, institutions or product-related skills or norms), whereas other authors use 'assets', 'resources' or 'localized capabilities' to describe the regional tacit knowledge and competence base as well as institutional environment that precede new regional paths (Boschma and Frenken 2006; Maskell and Malmberg 1999). Thus, although evolutionary theorizing highlights how, “once selected, [emphasis in the original] a new form of economic development, structure or technology may generate its own self-reinforcing processes [...], it is largely silent on the issues of how and where [emphasis in the original] that novelty comes from, or why one form of novelty gets selected over another” (Martin and Sunley 2006, 407).

Several authors now argue that more dynamic theories of path dependence are needed which explicitly unpack the mechanisms and processes that drive early regional branching and the emergence of new paths (Simmie 2012b; Henning, et al. 2013; Dawley 2014; Tanner 2014; Sydow, et al. 2012; Strambach and Halkier 2013). We argue that existing evolutionary frameworks would have to be extended in two main respects: First, to better understand the key mechanisms underlying early industry formation, one needs to look beyond knowledgebased and firm-centric accounts to include distributed and embedded agency in the sociotechnical alignment processes in the region (Dawley 2014). In particular, we will argue that a specification of the generic resources that actors mobilize in early path creation processes would help to better understand how routine diversification at the firm level co-evolves with 
broader organizational and institutional innovation in the region. Second, to avoid regional fetishism, extra-regional resources and the way they get accessed and anchored in these alignment processes needs to be integral part of the respective explanatory frameworks (Tanner 2014; Vale and Carvalho 2013). The next two sections will elucidate these two arguments in more detail.

\subsection{The need to look beyond organizational routines in path creation}

Before venturing into further conceptual discussion we define path creation as follows: “A new path is created in a region if it contains a set of functionally related firms and supportive actors and institutions that are established and legitimized beyond emergence and facing early stages of growth, developing new processes and products” (Vale and Carvalho 2013, 1022). This definition is in line with several recent contributions in EEG which argue that the recombination of firm-based organizational routines in a region co-evolves with wider set of non-firm actors (Tanner 2014; Gilbert and Campbell 2015), policy making (Dawley 2014; Gilbert and Campbell 2015), as well as institutional contexts (Dawley 2014; Simmie 2012a; Garud, et al. 2010; Simmie, et al. in press). Several empirical studies also unpacked how entrepreneurial actors engage in path de-locking (Martin 2010), path plasticity (Strambach and Halkier 2013) or active path creation (Dawley 2014; Tanner 2014; Sydow, et al. 2012; Garud, et al. 2010).

In these institutional and often narrative-based perspectives on path creation, “'initial conditions' are not given, 'contingencies' are emergent contexts for action, 'self-reinforcing mechanisms' are strategically manipulated, and 'lock-in' is but a temporary stabilization of paths-in-the-making” (Garud, et al. 2010, 760). Path creation is an iterative construction process in which networks of distributed actors jointly create new market segments and user profiles, adapt regulations, lobby for subsidies or define new technical standards and thereby ultimately create the conducive environment that helps a new industry develop and prosper in a region (Garud, et al. 2010; Garud and Karnoe 2003). New paths emerge not from external shocks, but from the strategic agency in heterogeneous actor groups that jointly act upon locked-in structures and mobilize resources to create a new industry (Sydow, et al. 2012; Karnøe and Garud 2012).

These perspectives respond to some of the criticism on EEG raised above: they apply a pronounced process-perspective on early industry formation, include non-firm actors and 
understand them as embedded in - and acting upon - institutional structure. They also challenge the pervasive focus on knowledge dynamics: Especially for industries that depend not only on codified scientific and technological (analytical) knowledge bases, but also on the creation of (more synthetic) new service and business models or demand-side dynamics, institutional structures and policy intervention move center stage (Asheim, et al. 2011; Dawley 2014; Martin and Moodysson 2013). Yet, this view to date has not created a detailed conceptualization of the resources and resource formation processes that the actors in an early industry can draw on (we will come back to this important caveat in section 3.1). Also, similar to conventional path dependence theory, these approaches have mainly emphasized industry formation processes stemming from regional and national contexts and overlooked how extraregional connections influence industry emergence in space.

\subsection{Specifying the role of extra-regional linkages in path creation}

The strong emphasis on endogenous regional diversification and branching processes has readily been criticized (Tanner 2014; Trippl and Tödtling 2007; Vale and Carvalho 2013; Grillitsch and Trippl 2013). In a globalizing knowledge-based economy, systematic and permanent mobilization of knowledge has become a key process for innovation and industrial growth (Crevoisier and Jeannerat 2009; Foray 2004). Emerging industries are accordingly influenced by dense local knowledge networks as well as extensive global pipelines or 'global buzz’ (Vale and Carvalho 2013; Bathelt, et al. 2004; Maskell, et al. 2006). Recent empirical studies furthermore underline the relevance of transnational entrepreneurship in early industry formation (Drori, et al. 2009; Sonderegger and Täube 2010; Saxenian 2007); E.g. Saxenian (2007) revealed that significant shares of Silicon Valley’s new ventures are initiated by immigrating entrepreneurs. Sonderegger and Täube (2010) found that the explorative growth phase of Bangalore's IT cluster was to large degree supported by international diaspora networks. Where first companies of a new industry locate is thus not only contingent on a region's initial generic resources, but increasingly by the regional actor's ability to mobilize external resources and anchor them in a regional entrepreneurial project (Martin and Sunley 2006; Crevoisier and Jeannerat 2009; Vale and Carvalho 2013).

With knowledge and entrepreneurial actors circulating in extensive international networks, "there is a move from specialization within regional production systems to more specific regional knowledge and resources within multi-location networks of mobility and anchoring” (Crevoisier and Jeannerat 2009, 1225). Anchoring is not simply about bringing external 
knowledge to the region, but about 're-contextualizing and diffusing it in place, supported by capable entrepreneurs, universities, new organizations, policy action and flexible institutional settings' (Vale and Carvalho 2013, 1021). It is a process in which extra-regional knowledge gets accessed by regional actors and subsequently used to transform regional structures. Building a strong anchor for external knowledge requires the build-up of supportive regional environments and localized interdependencies between firm and non-firm actors (Vale and Carvalho 2013). The process differs from embeddedness as it focuses on the movement of knowledge in space - away from the context where it was generated towards a new context where it interacts with existing knowledge and contexts in various ways (Crevoisier and Jeannerat 2009).

Summarizing this short discussion, an improved conceptual approach for path creation would enable a structured view on the distributed resource formation and alignment processes, as well as on the anchoring of external resources in the early industry formation phase. In the remainder we will sketch out how recent conceptual ideas from transition studies and the technological innovation systems (TIS) literature might provide promising first conceptual building blocks in this venture.

\section{Analytical framework: Key resources and anchoring in early path creation}

Transition and TIS studies emerged from evolutionary economics (Nelson and Winter 1982), innovation systems (Lundvall, et al. 2002) and the social construction of technology (STS) literatures (Bijker 1995). Over the last 20 years they integrated sociological and canonical understandings of path dependency in an elaborate research agenda that tries to understand the determinants of structural change in socio-technical systems (Geels 2010; Markard, et al. 2012). Especially TIS literature has built up a rich body of conceptual frameworks to understand the embryonic phases of new industries and validated them with extensive empirical case studies, mostly in emerging clean-tech sectors (Carlsson and Stankiewicz 1991; Jacobsson and Bergek 2011; Coenen and Truffer 2012). TIS research focuses on three conceptual building blocks: actors, networks and institutions (Markard and Truffer 2008; Bergek, et al. 2008a; Hekkert, et al. 2007). Actors are conceptualized in a broad sense to include companies (start-ups, spin-offs and incumbents), universities, government agencies, intermediaries (e.g. industry associations, NGOs), as well as end users. Networks include industry alliances, technical committees, working groups, regional innovation networks, or 
cluster organizations. The relevant institutional contexts are defined as the cognitive, regulative and normative rules that enable and constrain actor behavior, e.g. laws, technology regulations, routines, markets, culture. New (technological) paths are assumed to emerge out of alignment processes between these dimensions, i.e. from actors accumulating in a new industry, forming new alliances and networks and ultimately inducing changes to the relevant institutional contexts of the emerging industry (Bergek, et al. 2008a; Hekkert, et al. 2007).

\subsection{Resource formation and alignment processes in a TIS perspective}

Even though it originates from the same family as national and regional innovation systems, the TIS perspective is in various ways distinct from these. In fact, its distinguishing characteristics respond to some of the evolutionary critiques that have been recently raised against regional innovation systems for being largely static and descriptive (Uyarra 2009). TIS literature complements a more structural approach to innovation systems, often found in national and regional innovation systems or the broader literature on territorial innovation models (Moulaert and Sekia 2003) by emphasizing alignment processes between institutions and technologies (Truffer and Coenen 2012). It does also not set a priori territorial boundaries, but follows actors, networks, and institutions to 'wherever the analysis may lead' (Carlsson and Stankiewicz 1991). Another distinguishing feature is its process-based perspective on industry formation, conceptualized through a set of key system-building processes, as outlined in two programmatic papers by Bergek et al. (2008a) and Hekkert et al. (2007). The six key processes (knowledge creation, entrepreneurial experimentation, market formation, resource mobilization, creation of legitimacy, guidance of the search) can be interpreted as aggregates of the distributed agency in an emerging technological field, which form distinct resources for the actors involved in a new path as well as for the future evolution of the industry as a whole (Musiolik, et al. 2012). Specialized technological knowledge and competencies, market niches, technology standards, or government subsidies are examples of such resources that are emergent properties of the systemic interplay among the key actors of a TIS; they develop through distributed agency in heterogeneous actor networks, benefit all involved actors but cannot be easily controlled, owned or provided by one single actor group (Bergek, et al. 2008a; Musiolik, et al. 2012; Bergek, et al. in print).

Rather than starting from routines that are manifested at the firm level, industry formation is understood from resources that are co-created at the level of a technological innovation system (Musiolik, et al. 2012; Musiolik and Markard 2011). TIS studies understand resources 
similar to relational economic geography as socially constructed entities that rely on collective processes of resource generation and application (Bathelt and Glückler 2005). Yet, its list of relevant resources differs from economic geography: EEG mainly emphasizes knowledge as the key resource (Tanner 2014). Relational economic geographers in turn distinguish between four resource types - material resources, knowledge, power and social capital (Bathelt and Glückler 2005). TIS literature in turn proposed six key resource formation processes, which we condense into four analytically distinct key resources here: Knowledge, niche markets, technology legitimacy and financial investment.

Table 1: Key resources and resource formation processes for path creation

\begin{tabular}{llll}
\hline Key resource & Formation process & Definition & Indicators \\
\hline Knowledge & Knowledge creation & $\begin{array}{l}\text { Activities that create new technological } \\
\text { knowledge and related competencies, e.g. } \\
\text { learning by searching, learning by doing; } \\
\text { activities that lead to exchange of } \\
\text { information among actors, learning by } \\
\text { interacting and learning by using in } \\
\text { networks }\end{array}$ & $\begin{array}{l}\text { R\&D projects, no. of involved } \\
\text { actors, no. of workshops and } \\
\text { conferences, activities of industry } \\
\text { associations, linkages among key } \\
\text { stakeholders, spatial dynamics in } \\
\text { underlying knowledge networks }\end{array}$ \\
$\begin{array}{llll}\text { (Niche) } \\
\text { markets }\end{array}$ & Market formation & $\begin{array}{l}\text { Activities that contribute to the creation of } \\
\text { protected space for the new technology, } \\
\text { construction of new market segments }\end{array}$ & $\begin{array}{l}\text { Number of niche markets, } \\
\text { supportive tax regimes and } \\
\text { regulations, subsidies }\end{array}$ \\
Investment & $\begin{array}{l}\text { Investment } \\
\text { mobilization }\end{array}$ & $\begin{array}{l}\text { Activities related to the mobilization and } \\
\text { allocation of basic financial inputs such as } \\
\text { bank loans, venture capital or angel } \\
\text { investment }\end{array}$ & $\begin{array}{l}\text { Availability of financial capital } \\
\text { and complementary assets for key } \\
\text { actors, total sum of investment in } \\
\text { companies in the field }\end{array}$ \\
& $\begin{array}{l}\text { Activities that embed a new technology in } \\
\text { existing institutional structures or adapt the } \\
\text { institutional environment to the needs of } \\
\text { the technology }\end{array}$ & $\begin{array}{l}\text { Rise and growth of interest } \\
\text { groups and their lobbying } \\
\text { activities, institutional } \\
\text { entrepreneurship by the actors in } \\
\text { a new technological field }\end{array}$
\end{tabular}

Source: Compiled and adapted from (Bergek, et al. 2008a; Hekkert, et al. 2007; Musiolik and Markard 2011)

Economic geography and transition studies agree that knowledge lies at the heart of all path creation processes (Bergek, et al. 2008a; Bathelt and Glückler 2005) and that knowledge creation and recombination is the decisive mechanism through which firms create and sustain their competitiveness (Bathelt and Glückler 2005). In our framework knowledge is perceived of broadly as containing both explicit and tacit dimensions as well as experienced-based know-how and network-based know-who. Whereas some forms of knowledge are highly contextual and embedded in regional contexts, others are less sticky and easily transferrable in space. Early movers in a new field depend directly on creating and/or mobilizing this key resource. 
Second, niche markets are considered a resource here, as market segments for radically new technologies and products often do not pre-exist, but have to be created by the actors themselves (Fligstein 2007; Dewald and Truffer 2011; Kemp, et al. 1998). The early phase of the German solar photovoltaic (PV) industry might serve as an illustrative example: Until the mid-90ies a functional market for solar PV systems was missing globally. In the early 90ies, German technology experts, anti-nuclear activists and communal policy makers formed strategic alliances that constructed a new market segment (private rooftop solar systems) and lobbied regional policy making to adjust existing electricity grid regulations in favor of solar PV integration (Dewald and Truffer 2011). Once this market segment and related products were commoditized and a national feed-in tariff provided market support, the German PV path started booming. The German niche market consequently turned into a global resource that could get mobilized by new entrants to the industry in distant places (e.g. China) (Quitzow in print).

Financial investment, in turn, is a key and often scarce resource for the actors in a new industrial field (Hekkert, et al. 2007; Gustafsson, et al. in press). Especially in the very early industry formation phase, investment is often mobilized from various sources, containing angel investors, venture capital, as well as commercial and investment banks (Florida and Smith 1993; Corpataux, et al. 2009; Pollard 2003). As the commercial potential of the new products are uncertain, entrepreneurial actors will have to form stable alliances with investors and complementary actors to raise technology-specific expectations and secure sustained investment in the emerging path (Hekkert, et al. 2007; Bergek, et al. 2008b). Often, relevant shares of investment are also raised from government organizations or intermediary actors (e.g. associations and interest groups), in particular to fund R\&D or demonstration projects (ibid.).

Legitimacy, finally, depends on aligning the new industry and its products with the relevant institutional contexts (Aldrich and Fiol 1994; Johnson, et al. 2006; Markard, et al. submitted). New products and processes that are not aligned with the regulative, normative and cognitive institutions of a given place will be confronted with high skepticism and lacking user acceptance (Aldrich and Fiol 1994). To make the new industry and products appear as desirable, early proponents have to engage in considerable institutional work to either adapt the innovation to existing institutional structures or adapt these structures to better match the innovation’s needs (Bergek, et al. 2008b; Aldrich and Fiol 1994). Similar to the other resource 
formation processes, legitimation depends on interaction in heterogeneous actors networks (Binz, et al. submitted) and shows cumulative properties (Johnson, et al. 2006): Once an innovation is successfully validated in a local context, agents in another context will find it easier to diffuse the idea, e.g. through processes related to mimetic isomorphism (DiMaggio and Powell 1983).

These four key resources can be understood as necessary conditions for industry emergence: If any of them is missing, the emerging industry will face a significant development barrier. Path creation accordingly depends on how these four resources emerge out of the systemic interplay between relevant actors, networks and institutions, and the way they get aligned to each other (Suurs and Hekkert 2009). Measuring the resource formation processes and their alignment is challenging, as in the very early path creation phase many of the key components (firms, networks, institutions, policy interventions) are still embryonic and loosely coupled (Bergek, et al. 2008a). A range of qualitative indicators in Table 1 (derived mainly from TIS studies) is thus proposed to give rough measures of the intensity of these early alignment processes.

\subsection{Anchoring extra-regional resources in early path creation}

Whereas TIS studies so far mostly assessed how resources are mobilized from national or regional sources, recent work positions territorially agglomerated formation processes in the more or less densely connected networks of a wider global technological innovation system (Coenen, et al. 2012; Quitzow in print; Binz, et al. 2014; Binz, et al. 2012; Dewald and Fromhold-Eisebith 2015). Similar to knowledge, also other key resources do not necessarily emerge in densely localized settings only. Some might develop in other territorial subsystems and then get transplanted to a given region (Martin and Sunley 2006), while others might develop in transnational companies or global communities in a completely internationalized way (Binz, et al. 2014; Gosens, et al. 2015). In this perspective anchoring is not a onedimensional process of attracting external 'anchor tenants' that induce local knowledge spillovers (Feldman 2003), but an interactive process in which regional actors mobilize knowledge, markets, legitimacy and financial investment that emerge from formation processes in other regions of the global technological field. Over time, the extra-regional resources will get connected to the actors, networks and institutions that emerge in the region and after some time, agglomeration economies and self-reinforcing processes lead to selfsustaining regional industrial development paths. 
Assessing the performance of the resource formation and anchoring processes and their mutual alignment at different points in time can indicate if and how the key resources for industry formation are imported to or evolve in a given region. The more aligned these formation processes are in a region, the more resources get mobilized for local actors, and the stronger the anchoring of external resources and thus the better the conditions for the region to create a territorially distinct, path-dependent industrial path. In this approach we are in line with De Propris and Crevoisier (2011, 172), who suggest that "if regional growth is pursued through the anchoring of a new industry, this means transforming mobile factors into immobile factors to sustain a local process of firm agglomeration and knowledge accumulation.” Anchoring thus means coupling a region to extra-regional resources and transforming them into locally sticky (Asheim and Isaksen 2002) resources through activities that can be described by the four key resource formation processes. This framework allows for a differentiated analysis for identifying failures in specific resource formation or alignment processes, which could in turn inform policy makers aiming at the support of regional path creation (Jacobsson and Bergek 2011; See Bergek, et al. 2008a).

\section{Case selection and method}

The analytical framework laid out above will now be applied to assess the emergence of the on-site water recycling (OST) industry in China, a case in point for a new industrial path-inthe-making whose spatial evolution challenges existing relatedness-based explanatory frameworks.

\subsection{On-site water recycling (OST)}

On-site water recycling has emerged over the last 20 years as a significant alternative to conventional, centralized wastewater treatment technology. It is based on small, flexible wastewater treatment plants which can be installed into single buildings and recycle wastewater on-site. OST is considered a clean-tech industry with disruptive potential to the dominant development logic of the wastewater sector (Truffer, et al. 2012): Instead of relying on extended sewer networks and a centralized treatment system it is based on small, washingmachine-like treatment plants and decentralized operation and maintenance models. Whereas many of the basic technological components for OST plants are well developed, the relevant business models operation and maintenance concepts are not (Gebauer, et al. 2012). To date, the technology has mostly been applied in rural low-tech markets, which is served by small- 
to-medium sized companies that are widely distributed in space (Gebauer, et al. 2012). Path creation in our empirical example thus means that OST is starting to be mass-produced and applied in urban contexts, while inducing path-dependent industrial structures in specific regions.

OST represents an interesting case for our conceptual argument as innovation in this field is not only depending on R\&D-intensive technological advancements, but also on the development of new service and maintenance concepts, business models, as well as regulatory and institutional innovation. The case also promised interesting insights to the anchoring argument as OST technology is developing in a complex geographic actor structure: Embryonic OST industries have developed in Japan, South Korea, the USA as well as in Western Europe (Binz, et al. 2012; Truffer, et al. 2012) and the industry’s underlying knowledge network is strongly internationalized (Binz, et al. 2014). The industry thus promised interesting insights into how interaction between different regions of the global technological opportunity influences early path creation dynamics.

\subsection{Case study sites}

China was chosen as a focal area for this research for two main reasons: First, despite being a latecomer in the wastewater treatment field, it hosts some of the very few cities worldwide that have integrated OST systems in the urban core and developed its own emergent OST industry. Second, due to its very rapid development dynamics, China allows reconstructing path creation processes over a relative condensed timespan (less than 20 years). This has strong methodological advantages for this paper's qualitative research design: Many of the actors in the field experienced the full local history of the industry and could give detailed accounts on how the OST path emerged. ${ }^{2}$ China obviously also provides a very particular cultural and institutional setting for industry emergence (Fligstein and Zhang 2011; Nahm and Steinfeld 2014; Witt 2014). Yet, in the present paper we aim at illustrating the general utility of our analytical framework and thus refrain from an in-depth discussion of China's particular cultural context.

The cases for in-depth investigation inside China were selected based on purposive, theoretical sampling (Glaser and Strauss 1967), looking for both success and failure cases. 
Desk research showed that only in Beijing hosts a considerable OST industry: Six OSTrelated medium enterprises and one major international player in the OST field are located in this city region, which has more than 2'000 OST systems installed in its urban core. Its (relative) success story was chosen for the most detailed investigation whereas Shanghai and Xi'an are discussed as contrasting cases (for a more detailed discussion see Binz and Truffer forthcoming). The initial conditions differed considerably between the three regions (Table 2). Shanghai provided the most promising 'generic resources': When first OST experiments were undertaken in China, the city already had accumulated considerable experience with wastewater treatment technologies and had related industries in place. Beijing and Xi'an in contrast had less experience in the wastewater treatment field and provided considerably weaker related industrial capabilities, but were in turn confronted with more pressing water scarcity (Table 2, Jiang 2009). Beijing had an advantage in being the country’s scientific hub with access to key related knowledge bases, whereas Xi'an hosted a particularly active entrepreneurial research group in a local university that was pushing OST from the early 90ies. In sum, none of the three regions (maybe except for Shanghai) had a clear initial advantage in developing an OST industry. Still, Beijing was the only region where an embryonic OST path emerged. In the remainder we will explore this observation based on our analytical framework.

Table 2: Initial conditions of three Chinese cities, 1989

\begin{tabular}{|c|c|c|c|c|}
\hline & $\begin{array}{c}\text { Population }^{1} \\
\text { (Mio. Permanent } \\
\text { residents) }\end{array}$ & $\begin{array}{c}\text { Related industries }^{2} \\
\text { (Gross output value Mio. } \\
\text { Yuan, constant prices) }\end{array}$ & $\begin{array}{c}\text { Wastewater } \\
\text { treated } \\
\text { (Mio. Tons) }\end{array}$ & $\begin{array}{c}\text { Freshwater resources } \\
\text { per capita } \\
(\mathrm{m} 3 / \text { person*a })^{3}\end{array}$ \\
\hline Beijing & 7.3 & 95 & 375 & $300^{4}$ \\
\hline Shanghai & 8.2 & 319 & 930 & $1049^{5}$ \\
\hline Xi'an & 2.8 & 93 & 126 & $350^{6}$ \\
\hline
\end{tabular}

\subsection{Methods}

Reconstructing the resource formation and alignment processes in early industry formation requires the researcher to focus on social construction and actors making sense of emerging situations. The most powerful tools to assess them in-depth are expert interviews and qualitative content analysis (Sydow, et al. 2012; Yin 2009). In total, 40 interviews and five field visits to on-site treatment projects were conducted during an extended field stay in China 
between November 2010 and May 2011. Interviews covered relevant experts from all stakeholder groups involved in the process. Interview guidelines were structured according to the four key resources and alignment processes and adapted to each stakeholder group. All interview recordings were transcribed verbatim, translated and analyzed using qualitative content analysis (Glaser and Strauss 1967).

Table 3: Interviews in China

\begin{tabular}{|c|c|c|c|c|}
\hline $\begin{array}{l}\text { Stakeholder } \\
\text { group }\end{array}$ & $\begin{array}{l}\text { Interviews } \\
\text { Beijing (BJ) }\end{array}$ & $\begin{array}{l}\text { Interviews Shanghai } \\
\text { (SH) }\end{array}$ & $\begin{array}{l}\text { Interviews Xi'an } \\
\text { (XA) }\end{array}$ & Sum \\
\hline $\begin{array}{l}\text { Academia } \\
\text { (AC) }\end{array}$ & $\begin{array}{l}\text { Chinese Academy of Sciences (6), } \\
\text { Qinghua, Beijing S\&T University, Beijing } \\
\text { Forestry University, Renmin University }\end{array}$ & Tongji University (2) & $\begin{array}{l}\text { Xi'an University of } \\
\text { Architecture and } \\
\text { Technology }\end{array}$ & 13 \\
\hline $\begin{array}{l}\text { Domestic } \\
\text { Companies } \\
\text { (DC) }\end{array}$ & $\begin{array}{l}\text { Beijing Origin Water, Beijing Tooling, } \\
\text { Beijing Hujia-Hanqing, Beijing Qingyuan }\end{array}$ & $\begin{array}{l}\text { Shanghai 4F, Shanghai } \\
\text { Zizheng, PACT Shanghai }\end{array}$ & & 7 \\
\hline $\begin{array}{l}\text { Foreign } \\
\text { companies } \\
\text { (FC) }\end{array}$ & $\begin{array}{l}\text { Siemens, Veolia, GE, Kubota, } \\
\text { Hydranautics, Huber, Inge AG, DHV }\end{array}$ & Grundfos, Norit, ITT & & 11 \\
\hline $\begin{array}{l}\text { Policy experts } \\
\text { (PE) }\end{array}$ & $\begin{array}{l}\text { Renmin University, Chinese Academy of } \\
\text { Sciences (2) }\end{array}$ & $\begin{array}{l}\text { China Construction } \\
\text { Design Institute, Tongji } \\
\text { University, Korea } \\
\text { University }\end{array}$ & $\begin{array}{l}\text { Xi'an Municipal } \\
\text { Design Institute }\end{array}$ & 7 \\
\hline $\begin{array}{l}\text { Associations } \\
\text { (AS) }\end{array}$ & $\begin{array}{l}\text { International Water Association, Global } \\
\text { Water Intelligence }\end{array}$ & & & 2 \\
\hline Sum & 27 & 11 & 2 & 40 \\
\hline
\end{tabular}

To increase construct validity and avoid post-hoc rationalization, the interview data was triangulated with reports, internet databases, publications and company's annual reports in both English and Chinese. To guarantee anonymity, interviewees will be cited in the results section according to Table 3's abbreviations. E.g. an academician from Beijing would be named (ACBJ) and numbered.

\section{Emergence of an OST industry in Beijing}

Table 4 summarizes the current state of Beijing's OST industry. Six companies dominate the field and Beijing Origin Water has developed to an international leader, exporting its systems to Australia, Eastern Europe and Japan. In addition to these companies, about a dozen local research institutes are active in the OST field and two key international intermediary organizations established representative offices in Beijing. Overall, the OST path in Beijing is still in an early development phase, but meets our definition of early path creation: the city arguably contains a set of functionally related firms and supportive actors and institutions that 
are established and legitimized beyond emergence and facing early stages of growth, developing new processes and products.

Table 4: Key companies in Beijing’s OST industry

\begin{tabular}{lcccl}
\hline Company name & Founded & $\begin{array}{l}\text { Number of } \\
\text { employees }\end{array}$ & $\begin{array}{c}\text { Number of } \\
\text { plants installed }\end{array}$ & Main activity \\
\hline $\begin{array}{l}\text { Beijing Origin Water } \\
\text { 北京碧水源科技股份有限公司 }\end{array}$ & 2001 & 1 '625 & $>900$ & $\begin{array}{l}\text { Membrane manufacturing, } \\
\text { project design, system } \\
\text { integration, installation, } \\
\text { O\&M }\end{array}$ \\
$\begin{array}{l}\text { Beijing Ecojoy } \\
\text { 北京汉青天朗水处理科技有限公司 }\end{array}$ & 2002 & $30-50$ & $>50$ & $\begin{array}{l}\text { System integration, } \\
\text { installation, O\&M }\end{array}$ \\
$\begin{array}{l}\text { Beijing Tooling } \\
\text { 北京涛林环境工程有限公司 }\end{array}$ & 1999 & $30-50$ & $>300$ & $\begin{array}{l}\text { System integration, } \\
\text { installation, O\&M }\end{array}$ \\
$\begin{array}{l}\text { EnviroSystems } \\
\text { 万若环境 }\end{array}$ & 2003 & 25 & $>50$ & $\begin{array}{l}\text { Project design, system } \\
\text { integration, O\&M }\end{array}$ \\
$\begin{array}{l}\text { Beijing Wellhead } \\
\text { 北京万侯环境技术开发有限公司 }\end{array}$ & 1995 & $51-100$ & $>200$ & $\begin{array}{l}\text { Project design, installation, } \\
\text { O\&M }\end{array}$ \\
$\begin{array}{l}\text { Konckier Water } \\
\text { 北京康基亚环境工程有限公司 } \\
\text { Others }\end{array}$ & 2002 & $51-100$ & $>100$ & $\begin{array}{l}\text { Project design, system } \\
\text { integration, installation }\end{array}$ \\
\hline
\end{tabular}

Source: Triangulated data from interviews, company websites, reports and visits at trade fairs. ${ }^{3}$

O\&M: operation and maintenance

The history of this emerging industrial path started in the late eighties, at a time when wastewater infrastructure was still largely missing in Beijing and most other parts of China (Browder, et al. 2007; Fu, et al. 2008). Still, after a slow start, OST emerged in Beijing in a rather dynamic way and in three consecutive phases (Figure 2) which we will now assess in more detail.

\footnotetext{
${ }^{3}$ Note that while Beijing's OST industry has been growing rapidly, it is still not covered with official statistics, which complicates the creation of a comprehensive picture of all the activities in the field.
} 
Figure 2: Number of installed OST systems in Beijing (cumulative)

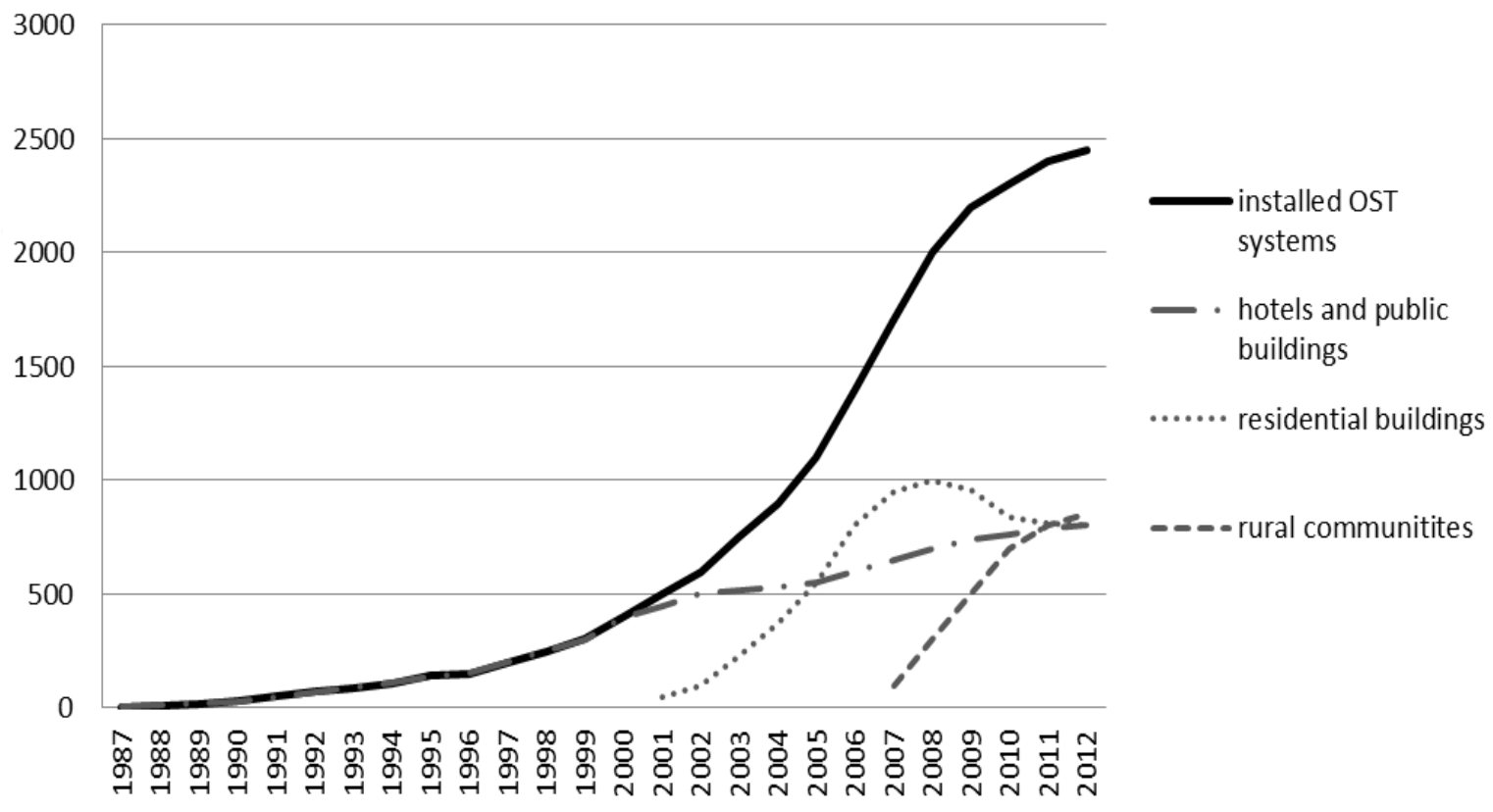

Source: Estimates from interviewees

\subsection{Beijing 1990-2001: OST gets introduced in a hotel market niche}

The first OST-related activities in Beijing emerged in the late 80ies after a relatively small change in Beijing's water policy (DCBJ, DCBJ3). In 1987, driven by increasingly pressing water scarcity, Beijing's local government formulated a new (provisional) regulation mandating hotels with a construction area exceeding $20{ }^{\prime} 000 \mathrm{~m}^{2}$ and public buildings with a construction area exceeding $30^{\prime} 000 \mathrm{~m}^{2}$ to introduce on-site water recycling facilities (Mels, et al. 2007, DCBJ1, DCBJ2, DCBJ3). At the time, the indigenous technological know-how even for centralized wastewater treatment was still very limited, so in order to comply with this regulation, hotels had to refer to international companies (mainly from Japan, Germany and France) for help with project planning and implementation (DCBJ2). At that time, innovation thus mainly happened in foreign companies that had experience with rural application of OST technology and developed new and improved technological solutions for the new market in large hotels. In addition, many large hotels in the city were run by international hotel chains, so not only was the first OST niche in Beijing served by foreign companies, but also the initial investments and customers originated from outside the region (DCBJ2). 


\section{Key resources and alignment processes}

At this early stage, knowledge (state of the art technology, O\&M concepts and qualified engineers) was mostly imported from elsewhere by introducing products of Japanese and European OST companies and engineers into the hotel niche (Binz, et al. 2012). Initially, numerous foreign SME's competed in Beijing's small hotel market, but none of them could gain a dominant market share (DCBJ2). Only at the end of this first period did small Chinese engineering companies from regional heating, steel piping and water supply sectors start copying products of their international competitors and supplying very cheap but also largely dysfunctional own products (DCBJ1). At this early stage, also academic knowledge creation in Beijing was strongly dependent on dense interaction with OST research groups outside Beijing, mainly in Europe, Japan and the USA (Binz, et al. 2014, ACBJ1): A research group from Qinghua University got included into the global research network of a transnational water company and developed quickly into a globally leading group in membrane bioreactor technology, a core process for OST systems (ibid.). Still, the local universities and research institutes started experiments with their first local OST pilot plants only in the late 90'ies (ACBJ3, ACBJ2) and their activities were rather explorative, aimed at scientific discoveries and not yet connected to local industrial partners (ACBJ4, ACBJ3).

Legitimacy of OST was not highly contested as there was general agreement on the need of new water saving technologies for this very water scarce city (ACBJ5). Also, while OST was in conflict with several regulative institutions in the city's residential water sector governance, the hotel niche was a special case with its own particular selection environment. Legitimacy was also created in other regions around the world where OST got locally validated in rural application niches. The positive experience with international systems in large hotels helped later diffusion of the technology: Thanks to international management, professional operation and economic profitability of OST systems in large hotels, local engineers and practitioners first realized the full potential of the idea (DCBJ2) and local universities started taking up OST as a field of study (ACBJ2, ACBJ1). Finally, as the hotel market in Beijing was strongly driven by extra-regional networks, also investment was mainly mobilized through the presence of foreign actors and the investment decisions by international hotel chains.

In sum, the only key resource formation process which can be attributed to a regional scale in Beijing in the first phase is niche market formation: By introducing the hotel regulation, Beijing's government created a protected space for technology experimentation that made 
local actors start to perceive the OST systems' market potential, commodify first products and develop experimental pilot plants. At the end of the nineties, OST in Beijing was a regulationdriven market niche, which was strongly coupled to key resources developing outside China. Still, the legitimacy, knowledge, niche markets and investment induced at that time proved to be decisive for later path creation phases.

\subsection{1-2007: Entrepreneurial experimentation in residential buildings}

At the beginning of the new millennium and based on the positive experiences from the hotel market, Beijing's government decided to extend its on-site water recycling regulation to residential development areas (DCBJ1, ACBJ2). Starting from 2003, new residential construction projects exceeding a total floor surface of 50'000 $\mathrm{m}^{2}$ were forced to install onsite water recycling facilities (Mels, et al. 2007, DCBJ1 4, DCBJ4, DCBJ5). As real estate construction was booming at the time, this legislation meant that most new residential projects in Beijing had to include on-site systems (ACBJ2).

\section{Key resources and alignment processes}

First and foremost, this small addition to existing regulation opened an additional and considerably large market in which local and external actors could further experiment and commoditize their OST products. Apart from this most direct effect, the new market niche also lead to a surge in the other resource formation and alignment processes. Considerable financial investment got mobilized for the local industry; as the real estate developers were basically forced to integrate OST systems into their new projects, they installed locally sourced OST systems (DCBJ1) and spread the additional costs to the tenants through higher apartment rents (FCBJ1).

As the demand and available investment for on-site systems skyrocketed, new companies got founded that started creating crucial new knowledge. All of our interviewed companies were established around the year 2000, either as spin-offs from local universities (DCBJ5, DCBJ6), or by entrepreneurs returning from Europe, Japan or Australia (DCBJ4, DCBJ3, DCBJ6). According to the interviewees from local companies, their main motivation to found companies was not connected to the available 'generic resources' in Beijing, but to a sense of opportunity in mobilizing their foreign specialized technological knowledge and anchoring it in a unique learning environment in their (institutionally and socially proximate) hometown. In the first few years, these entrepreneurs took advantage of Beijing's enabling environment 
by engaging in "learning by doing” (DCBJ3, DCBJ1): They developed new technological OST concepts, installed them into residential buildings and then learned on the spot about the technological and organizational challenges (DCBJ1). ${ }^{4}$ In this process, local actors increasingly took over the hotel market segment from international companies which started pulling out of the strongly competitive market (DCBJ1). Together with learning by doing in the industry, knowledge creation also got aligned with local universities (ACBJ1). Many research institutes started getting in cooperation with local companies, either because some of their graduates launched own companies (DCBJ5) or because start-ups needed scientific expertise in the configuration and early operation of their OST plants (DCBJ4). Knowledge creation now happened in increasingly distributed local networks, especially with start-ups and research organizations involved in intensive reciprocal learning. As much of academia was at the same time strongly linked internationally, this setup facilitated the constant translation of international best practices into Beijing's emerging OST industry (ACBJ1).

Finally, despite the emergence of an increasingly vibrant innovation system in the OST field, Beijing's emerging path later ran into a serious legitimacy crisis: After about five years the market segment in residential buildings turned into a failure, mainly due to inconsistencies between the technology's needs and the institutional context in this specific market segment (DCBJ1, DCBJ3, DCBJ5, ACBJ2, ACBJ3). In residential buildings, professional operation and maintenance of OST plants could not be guaranteed, and the price structure in Beijing's water sector was such that residential OST plants could not be operated profitably ( $\mathrm{Li}$, et al. 2013, ASBJ1, ACBJ5). According to our interviewees, only about 10-20\% of the systems initially installed in residential districts are still fully operational today (DCBJ1, ACBJ2, DCBJ3). This failure eroded trust from residential end-users and experts and strongly delegitimized OST in Beijing. Even though by the mid-2000's the local industry had built up basic technological and organizational know-how, the dire institutional context in the residential market made OST increasingly look like an undesirable solution (ACBJ6). Had there not been the still successful hotel market niche and a quickly growing local industry, the OST path would probably have ended in complete de-legitimization at this point in time (DCBJ4).

\footnotetext{
${ }^{4}$ A process similar to what Garud and Karnoe (2003) called ‘bricolage’.
} 
In sum, in the second phase several resource formation processes got more aligned and extraregional knowledge that had entered the region in the first phase got increasingly anchored locally in a dynamic entrepreneurial experimentation process. One crucial anchoring process in that time was triggered by returning highly skilled experts, which saw an opportunity in using their externally acquired know-how to establish companies in a globally quite unique environment that supported experimentation and interactive learning. Linkages to other important regions the global field of technology also remained crucial, especially through the internationally well connected regional science system.

\subsection{7-2012: Industry consolidation and intensified resource alignment}

Despite the fiasco in the residential market, Beijing's OST path continued developing in a third phase and the industry got embedded in an increasingly vibrant OST-related innovation system: Industry-science interaction further intensified, specialized OST research groups were established and international advocacy coalitions for OST systems located in the city (ACBJ8). The biggest industrial player, Origin Water, started to manufacture a massproduced standardized treatment plant that became a template for other OST firms inside and outside Beijing (DCBJ5). The company developed into a global leader in water recycling technology and is now a direct competitor to major international players like GE, Siemens or Kubota. The actor base stabilized and interpersonal guanxi ${ }^{5}$-ties between industry, academia and the local authorities got denser (DCBJ1) ${ }^{6}$. Concomitantly, the experience of Beijing started radiating to other places and advocacy coalition for rural OST systems developed increasing visibility throughout China (ACBJ7, ACBJ8).

\section{Key resources and alignment processes}

Knowledge creation further intensified in this last phase, both inside and beyond Beijing's immediate context: With an increasing national push for infrastructure build-up in rural areas, a research institute of the Chinese Academy of Science in Beijing applied for national funding for a competence center for rural OST systems. The center was approved and is now running large scale field studies that try to find suitable technologies and maintenance schemes for OST systems (ACBJ7, ACBJ8). Some successful experiments got published as cover stories in highly prestigious national technology magazines (ACBJ8). Also international advocacy

\footnotetext{
${ }^{5}$ Interpersonal ties, based on reciprocity, a very important structural element of Chinese society, (see e.g. Xin and Pearce 1996)

${ }^{6}$ In the Chinese context this is a clear indication that the emerging path has matured to some degree
} 
coalitions for OST systems started knowledge dissemination and lobbying activities, mainly through highly devoted academics and entrepreneurs (ACBJ2, DCBJ3). The international Water Association organized high-profile conferences on OST systems in Xi'an and Harbin ${ }^{7}$, further linking scientist in the field both inside China and with different experts from other key subsystems of the global technological opportunity set (ASBJ2).

The small but well-connected advocacy coalition in Beijing's OST industry could also successfully lobby the local government to further expand market formation to the rural fringe of Beijing (DCBJ1). An advocacy coalition around the regional industry champion, Origin Water, convinced Beijing's government to start installing OST systems in environmentally sensitive suburban areas around the city (DCBJ4). Learning from the failures in the residential market, new technological solutions and a comprehensive operation and maintenance system were developed with engineers permanently repairing distributed systems. At the same time, OST markets increasingly developed in other regions of China, especially in Southern rich rural areas and in water scarce cities in Northern and Western China (ACBJ8, DCSH1, DCSH2). Most companies in Beijing accordingly diversified into suburban, rural or industrial markets (DCBJ5, DCBJ1). In addition, Japanese OST companies entered China again, this time targeting the emerging suburban and rural market segments (FCBJ2). OST systems still had to be installed in hotels and new residential developments (ACBJ2, PEBJ1), but these two market segments now slowed down (DCBJ3, FCBJ2, DCBJ5).

In terms of investment mobilization, new pools for funding got available from two main sources. First, several national and regional R\&D programs allocated funding to OST projects in Beijing's universities and research institutes and new subsidy schemes for rural OST systems were developed in various Southern provinces. Second, in April 2010, the IPO of Beijing Origin Water at the Shenzhen Stock Exchange mobilized an additional extra-regional source of investment for the further development of OST technology in Beijing. ${ }^{8}$ Similarly, in the last phase, several actors of the Beijing OST industry developed a coordinated lobbying strategy, which helped them save OST's damaged legitimacy (DCBJ4, DCBJ3). All of the interviewed company managers claimed that they invested heavily in making presentations at conferences and symposia in order to educate key stakeholders about the benefits of OST

\footnotetext{
7 'Cities of the future Xi'an: technologies for integrated urban water management' (Xi'an, 2011); 11th IWA Conference on Small Water \& Wastewater Systems and Sludge Management (Harbin, 2013)

${ }^{8}$ By 2015, Origin Water had a market capitalization of more than 5 bn. US\$.
} 
systems in residential and non-residential markets and to further stabilize basic government support and technology legitimacy with end-users and experts (DCBJ3, DCBJ5, DCBJ4, DCBJ1).

In sum, after a complex resource formation, anchoring and alignment process, lasting about 20 years, the small OST industry in Beijing started providing regionally confined spillover effects to its local actor base that EEG would recognize as a new regional path: the local science system produces a steady flow of specialized engineers that are taken up by the local industry, Beijing's companies export their systems throughout China and internationally and re-invest their revenues into the build-up of large cutting-edge production facilities in the city’s suburbs. ${ }^{9}$ Also, interactive learning between local industry, city planners and academia has created an OST-related innovation system that increasingly attracts outside experts to study the city's OST experience, ${ }^{10}$ thereby further extending the regional knowledge base. Even though the future development of OST is hard to predict, Beijing mobilized and anchored the key resources to further develop its local path in this emerging industry.

\subsection{Discussion}

Table 4 further summarizes the resource formation processes in Beijing's OST industry in the three observed development phases. Resource formation changed from an extra-regionally dominated to a regionally anchored setup: Whereas most of the key resources were imported from outside the city in a first phase, they were gradually transformed to endogenous regional resources in later development stages. In a nutshell, Beijing's success in creating an OST path lies in a three-step anchoring process: First regional actors mobilized experts and access to resources from other places through opening a small market niche to foreign companies. The basic knowledge, investment and legitimacy mobilized in this small market niche motivated highly skilled returnee entrepreneurs to found de-novo start-ups and local actors to start spinoffs from related sectors and local universities. Second, the imported cutting edge know-how increasingly transformed local market, investment and knowledge structures in a localized learning-by-doing process. Finally, most resource formation processes were retained and aligned in a regional, yet internationally well-connected innovation system forming around OST technologies. Beijing’s path in OST technology emerged from the interplay among

\footnotetext{
${ }^{9}$ See www.originwater.com

${ }^{10}$ E.g. a EU-funded, global research project (SWITCH) devoted a whole chapter to studying and improving Beijing's OST systems. http://www.switchurbanwater.eu/cities/3.php, accessed 21.10.2014
} 
industrial, academic and governmental actor groups, which drew on both local and extraregional sources to mobilize and align the knowledge, markets, investment and legitimacy needed for industry formation. Interestingly, this process was not intended or planned from the outset but emerged out of the local and extra-regional alignment dynamics driven by distributed actor networks in Beijing's context.

Applying the same analytical perspective to Shanghai and Xi' an (for a more comprehensive discussion see Binz and Truffer forthcoming) reveals that the different resources for industry formation were not aligned in an equally balanced way. The actor networks in these regions did either not mobilize key regional resources or failed to anchor them from extra-regional sources. Shanghai at the outset had strong technological relatedness and connections to key global water technology companies in place, but no notable OST path emerged. Rather, the regional actors relied on investments from international donor agencies and a large transnational water company to build up an extensive conventional centralized wastewater infrastructure (Lee 2006). The city’s water industry accordingly got locked-in to producing components for large-scale centralized wastewater treatment plants. Missing knowledge creation and market formation additionally hindered Shanghai from developing an OST path: The city's universities did for a long time not develop curricula in OST technologies and there was no regulation-driven market niche as well as no experience in related market segments like district heating (which was readily available in Beijing).

In Xi'an, in turn, knowledge creation was strongly pushed by an entrepreneurial returnee professor, but other key resource formation and anchoring processes were missing: His research group at Xi'an University of Architecture and Technology induced several large research projects on OST and convinced the local government to plan and fund local pilot projects (Wang, et al. 2008). These projects were broadly considered a success and created legitimacy for OST beyond the regional borders. Still, Xi’an’s path formation process remained strongly centered on this single key actor and never initiated distributed learning, market formation, investment mobilization or a wave of start-ups like in Beijing. This single anchor tenant was unable to mobilize and align all the key resources for successful industry formation. The comparison with Beijing reveals that especially demand-side effects and the succession of a set of differing market segments might have been a crucial missing factor in Xi’an. 
2 Table 4: Summary of the performance of key TIS building processes in Beijing

\begin{tabular}{|c|c|c|c|c|c|}
\hline & & Knowledge creation & Market formation & Creation of Legitimacy & Investment mobilization \\
\hline \multirow[t]{2}{*}{$\begin{array}{l}\text { Hotels } \\
\text { 87-00 }\end{array}$} & $\begin{array}{l}\text { Extra- } \\
\text { regional }\end{array}$ & $\begin{array}{c}++ \\
\text { Knowledge imported to Beijing by } \\
\text { foreign OST companies }\end{array}$ & & $\begin{array}{c}+++ \\
\text { Positive experience with imported } \\
\text { hotel systems legitimizing OST }\end{array}$ & $\begin{array}{c}++ \\
\begin{array}{c}\text { Initial investment provided by } \\
\text { international hotel chains }\end{array}\end{array}$ \\
\hline & Regional & $\begin{array}{l}\stackrel{+}{\text { Learning in the hotel niche and first }} \\
\text { research in Beijing's science system }\end{array}$ & $\begin{array}{l}++ \\
\text { Beijing's city government creating a } \\
\text { protected market niche in hotels }\end{array}$ & & \\
\hline \multirow[t]{2}{*}{$\begin{array}{l}\text { Resi- } \\
\text { dential } \\
\text { 00-07 }\end{array}$} & $\begin{array}{l}\text { Extra- } \\
\text { regional }\end{array}$ & $\begin{array}{c}+++ \\
\text { external knowledge imported } \\
\text { through academia, companies and } \\
\text { returning experts }\end{array}$ & & $\begin{array}{c}++ \\
\text { Returnee entrepreneurs lobbying for } \\
\text { and promoting OST }\end{array}$ & \\
\hline & Regional & $\begin{array}{c}++ \\
\text { Tight industry-university linkages, } \\
\text { spin-offs from local research } \\
\text { institutes } \\
\end{array}$ & $\begin{array}{l}\qquad+++ \\
\text { Beijing's city government extending } \\
\text { OST regulation to residential projects }\end{array}$ & $\begin{array}{c}\text {--- } \\
\begin{array}{c}\text { Massive failures in the residential } \\
\text { market }\end{array}\end{array}$ & $\begin{array}{l}\qquad++ \\
\text { Local real estate developers paying } \\
\text { investment costs for OST plants }\end{array}$ \\
\hline \multirow[t]{2}{*}{$\begin{array}{l}\text { Rural } \\
07-12\end{array}$} & $\begin{array}{l}\text { Extra- } \\
\text { Regional }\end{array}$ & $\begin{array}{c}+ \\
\text { external knowledge imported } \\
\text { through international organizations, } \\
\text { academia }\end{array}$ & $\begin{array}{c}+ \\
\text { Beijing industry serving markets in } \\
\text { other regions of the global TIS }\end{array}$ & & $\begin{array}{c}+ \\
\text { Beijing Origin getting listed at Shenzhen } \\
\text { stock exchange, raising international } \\
\text { investment }\end{array}$ \\
\hline & Regional & $\begin{array}{c}+++ \\
\text { University-industry linkages, } \\
\text { specialized research groups, } \\
\text { associations emerging in Beijing }\end{array}$ & $\begin{array}{l}\text { Beijing actors lobbying for and } \\
\text { constructing a new market niche in } \\
\text { rural areas }\end{array}$ & $\begin{array}{c}++ \\
\text { Company managers and system } \\
\text { intermediaries holding presentations, } \\
\text { educating key stakeholders on OST }\end{array}$ & $\begin{array}{l}\qquad++ \\
\text { Local companies mobilizing investments } \\
\text { from local government and real estate } \\
\text { developers }\end{array}$ \\
\hline
\end{tabular}


2 Three main insights stand out from these results. First, our evidence shows that the path

3 creation process depended equally on regional and extra-regional key resources: One part of

4 Beijing's success is explained by the fact that it was able to attract foreign technology, companies and later knowledgeable experts and entrepreneurs. Another part is then attributable to the fact that it was able to retain these elements and continuously mobilize them regionally. In contrast to the original concept by Crevoisier and Jeannerat (2009) the observed anchoring process did however not only refer to knowledge, but also to the mobilization and alignment of other key resources like market access, technology legitimacy and investment. Second, system building dynamics on the demand side (the succession of a set of differing, yet related market segments, as well as pre-existing competence in operating and maintaining related technologies like heating and boiler systems) was a crucial success factor in Beijing. ${ }^{11}$ This finding supports recent claims that evolutionary theories would have to be adapted to include demand-side relatedness more strongly in their path creation concept (Tanner 2014; Gilbert and Campbell 2015).

Third and finally, our results confirm that government interventions are to be seen a key ingredient (but far from determinant) for industrial path creation (in line with recent findings from Dawley 2014). In the OST case the local government interventions played an important role especially in fostering the protected niche markets in which other resource formation and alignment processes could take shape. Especially in the Chinese context, local and central governments are often assumed to play a key role in supporting new industrial paths (Nahm and Steinfeld 2014; see e.g. Gallagher 2014). In the present case, however, government actors were not steering the development process with rigid, top-down industrial policies, but were rather experimenting with tentative policies and reacting to industry scale-up and emerging advocacy coalition’s lobbying efforts. Even in China’s centralized governance system, government actors alone could thus not induce the complex distributed agency and all resources needed for industry formation.

\footnotetext{
${ }^{11}$ This result is in line with earlier work on market formation in a TIS context that proved the importance of different market segments for building up a PV industry in Germany (Dewald and Truffer 2011).
} 


\section{Conclusions}

2 This paper set out to develop an analytical framework for path creation which explicitly unpacks the generic resources and early resource formation processes that drive the emergence of new industrial paths. We argued that evolutionary economic geography's emphasis on endogenous branching processes from (pre-)existing industries and firm-based organizational routines in the region is downplaying the role of non-firm actors, institutions, policy intervention as well as non-local linkages. The presented analytical framework broadens existing knowledge-centric accounts with additional explanatory dimensions (markets, investment, and legitimacy) and adds a new perspective on how these resources get mobilized, aligned and anchored in the early path creation phase. In our view, industrial path creation in a region is not only depending on the degree of technological relatedness that is in place at the outset, but also to the distributed agency in the very early industry formation phase, e.g. the way early actors mobilize and anchor key resources for industry formation both from inside and outside the region.

Instead of relying on knowledge dynamics as the key generic resource, we used recent insights from transition and innovation studies to further specify and distinguish between four resources. Disentangling the actor networks and institutional contexts of knowledge creation, market formation, legitimation and the mobilization of financial investment helps extending the explanatory variables of path creation concepts beyond firm-based organizational routines and knowledge dynamics. As EEG and TIS/transitions share the same roots in evolutionary economics, our framework furthermore builds constructive bridges between the - as McKinnon et al. (2009) rightfully state - often unnecessarily divided streams of evolutionary, institutional and relational economic geography. While technological relatedness and firm routine diversification play a key role in our framework, they are also put into the broader perspective of a more distributed innovation process in the relevant institutional, market and finance contexts. Each of the identified four key resources can be expected to evolve in their specific path- and place-dependent trajectories, similar to what has been broadly assessed for the knowledge dimension. Future work could set out to analyze these resource formation processes in more detail and develop new hypotheses on the specific forms of relatedness that influence their spatial evolution.

Second, we specified the spatial origin of generic resources in more detail by relying on the anchoring concept. Knowledge, niche markets, investment or even legitimacy do not 
necessarily have to get mobilized from inside the region. They might as well develop in related actor networks outside the region and then be anchored to the regional path creation process through the activities of transnational entrepreneurs, international donor organizations, global investment banks, multi-national corporations or travelling technocrats. Further analysis how this anchoring of extra-regional resources works would be of particular importance to create more nuanced explanations of why new paths emerge or get 'transplanted from elsewhere' (Sunley 2008) to specific regions while they fail to develop in other regions with similar or even better technological relatedness and generic resources in place (Dawley 2014).

In summary, we thus maintain that the presented framework helps develop more nuanced answer to the fundamental questions how and where new industries emerge and if they need the local presence of related industries (Boschma and Martin 2010, 29). Based on our framework and case study we argue that new industries depend on co-evolving territorial and socio-technical embedded innovation processes and - arguably increasingly important linkages to other regions in the global innovation system forming around a new technology. This paper and other recent empirical cases (Tanner 2014; Quitzow in print; Gosens and Lu 2013) show that technological (and other forms of) relatedness are key necessary conditions for industry formation (Boschma and Frenken 2011a), but to understand how and where these pre-existing resources induce structural change, one has to include a broader view on system formation, resource alignment and anchoring of extra-regional resources.

It goes without saying that the findings presented above leave space for further improvements. First, our single case study design limits the direct generalizability of our results. OST technology was chosen as an extreme case that illustrates the innovation challenges in an infrastructure sector that relies on synthetic knowledge bases and interactive learning by doing. As such, the observed patterns might be most informative for similar industries, e.g. in other infrastructure-related emerging clean-tech fields like wind power, biofuels or electric mobility. Future studies would have to assess how they differ in emerging industries with more analytic or symbolic knowledge bases. In addition, China provides a quite unique institutional context for path creation processes, which we could not explore in much detail here. Our results are thus to be understood as mostly analytically generalizable, meaning that the developed framework could (and should) be applied to emerging sectors in different 
1 sectorial and regional contexts to further validate it and expand its explanatory power

2 (Dawley 2014; Tanner 2014).

3

4 Second, we only had limited space to discuss each key resource for industry formation in much detail here. Future work should use literature from related fields of the social sciences to further specify each resource and disentangle their relevant sub-dimensions. E.g. legitimation could be further specified by relating to institutional sociology literature and the key dimensions of investment mobilization could be reframed based on recent insights from business literature or more critical political ecology perspectives. Also power and social capital were not explicitly included in our list of resources. Whereas a thorough discussion of power was beyond the scope of this paper, we do not deny the possibility that this important dimension could be included in the proposed framework. Social capital was implicitly conceptualized as an emergent outcome of the increasing interaction in an emerging TIS; as new actor networks emerge and engage in knowledge creation, market formation, investment mobilization and technology legitimation, the social capital available to the actors in the systems was expected to grow. Future work could conceptualize this important process in more detail.

Finally, our results show that transnational entrepreneurs appear to be in a unique structural position to perceive development potentials that are invisible to purely regionally embedded actors. While we could not explore this topic in much depth here, this finding resonates with insights in cluster studies (Saxenian 2007; Giuliani and Rabellotti 2012; Yeung 2009) and could be further scrutinized in related research.

\section{References}

Aldrich, H. E., and Fiol, C. M. 1994. Fools rush in? The institutional context of industry creation. The Academy of Management Review 19:645-670.

28 Asheim, B. T.; Boschma, R.; and Cooke, P. 2011. Constructing Regional advantage: Platform 29 policies based on related variety and differentiated knowledge bases. Regional Studies 30 45:893-904.

31 Asheim, B. T., and Isaksen, A. 2002. Regional innovation systems: The integration of local

32 'sticky' and global 'ubiquitous' knowledge. Journal of Technology Transfer 27:77-86. 
Asheim, B. T.; Bugge, M. M.; Coenen, L.; and Herstad, S. 2013. What does evolutionary economic geography bring to the policy table? Reconceptualising regional innovation systems. Circle Electronic Working Paper Series no. 2013/05

Bathelt, H.; Malmberg, A.; and Maskell, P. 2004. Clusters and knowledge: local buzz, global pipelines and the process of knowledge creation. Progress in Human Geography 28:31-56.

Bathelt, H., and Glückler, J. 2005. Resources in economic geography: From substantive concepts towards a relational perspective. Environment and Planning A 37:1545-1563.

Bergek, A.; Hekkert, M.; Jacobsson, S.; Markard, J.; Sanden, B.; and Truffer, B. in print. Technological Innovation Systems in contexts: towards an improved conceptualization of 10 contextual structures and interaction dynamics. Environmental Innovation and Societal 11 Transitions

Bergek, A.; Jacobsson, S.; Carlsson, B.; Lindmark, S.; and Rickne, A. 2008a. Analyzing the functional dynamics of technological innovation systems: A scheme of analysis. Research Policy 37:407-429.

Bergek, A.; Jacobsson, S.; and Sandén, B. A. 2008b. 'Legitimation' and 'development of positive externalities': Two key processes in the formation phase of technological innovation systems. Technology Analysis and Strategic Management 20:575-592.

Bijker, W. 1995. Of Bicycles, Bakelites, and Bulbs: Toward a Theory of Sociotechnical Change. Cambridge: MIT Press.

Binz, C.; Sedlak, D.; Harris-Lovett, S.; Kiparsky, M.; and Truffer, B. submitted. Legitimizing system innovation - How support for potable water reuse was constructed in California.

\section{Technological Forecasting \& Social Change}

Binz, C., and Truffer, B. forthcoming. Cities as mediators between local niches and global networks, The transition to onsite water recycling in three Chinese cities. In Urban Sustainability Transitions, ed. N. Frantzeskaki, L. Coenen, V. Castan Broto and D. Loorbach, London: Routledge.

Binz, C.; Truffer, B.; and Coenen, L. 2014. Why space matters in technological innovation systems - The global knowledge dynamics of membrane bioreactor technology. Research Policy 43:138-155.

Binz, C.; Truffer, B.; Li, L.; Shi, Y.; and Lu, Y. 2012. Prospective analysis of leapfrogging trajectories - An analytical framework and a case study in the Chinese wastewater sector. Technological Forecasting and Social Change 79:155-171.

Boschma, R., and Frenken, K. 2011a. Technological relatedness and regional branching. In Beyond territory. Dynamic Geographies of knowledge creation, diffusion and innovation, ed. H. Bathelt, M. P. Feldman and D. F. Kogler, 64-81. London and New York: Routledge. Elgar. 
1 Boschma, R., and Frenken, K. 2011c. The emerging empirics of evolutionary economic

2 geography. Journal of Economic Geography 11:295-307.

3 Boschma, R.; Minondo, A.; and Navarro, M. 2012. Related variety and regional growth in

4 Spain. Papers in Regional Science 91:241-256.

Boschma, R. A. 1997. New industries and windows of locational opportunity: a long-term analysis of Belgium. Erdkunde 51:12-22.

Boschma, R. A., and Frenken, K. 2006. Why is economic geography not an evolutionary science? Towards an evolutionary economic geography. Journal of Economic Geography 9 6:273-302.

Boschma, R. A., and Frenken, K. 2009. Some notes on institutions in evolutionary economic geography. Economic Geography 85:151-158.

Boschma, R. A., and Martin, R. 2010. The aims and scope of evolutionary economic geography. In The handbook of evolutionary economic geography, ed. R. Boschma and R. Martin, 3-39. Cheltenham: Edward Elgar.

Breschi, S., and Lissoni, F. 2001. Localised knowledge spillovers vs. innovative milieux: Knowledge "tacitness" reconsidered. Papers in Regional Science 80:255-273.

Browder, G.; Xie, S.; Kim, Y.; Gu, L.; Fan, M.; and Ehrhardt, D. 2007. Stepping Up Improving the performance of China's water utilities. Washington DC: The World Bank.

Carlsson, B., and Stankiewicz, R. 1991. On the nature, function and composition of technological systems. Journal of Evolutionary Economics 1:93-118.

Coenen, L.; Benneworth, P.; and Truffer, B. 2012. Toward a spatial perspective on sustainability transitions. Research Policy 41:968-979.

Coenen, L., and Truffer, B. 2012. Places and Spaces of Sustainability Transitions: Geographical Contributions to an Emerging Research and Policy Field. European Planning Studies 20:367-374.

Cooke, P. 2004. Introduction: Regional innovation systems - an evolutionary approach. In Regional Innovation Systems, ed. P. Cooke, M. Heidenreich and H. Braczyk, 1-18. London: Routledge. 2nd edition.

Corpataux, J.; Crevoisier, O.; and Theurillat, T. 2009. The expansion of the finance industry and its impact on the economy: a territorial approach based on Swiss pension funds. Economic Geography 85:313-334.

Crevoisier, O., and Jeannerat, H. 2009. Territorial knowledge dynamics: From the proximity paradigm to multi-location milieus. European Planning Studies 17:1223-1241.

Dawley, S. 2014. Creating new paths? Offshore wind, policy activism, and peripheral region development. Economic Geography 90:91-112. 
1 De Propris, L., and Crevoisier, O. 2011. From regional anchors to anchoring. In Handbook of

2 Regional Innovation and Growth, ed. P. Cooke, 167-177. Cheltenham: Edward Elgar.

3 Dewald, U., and Truffer, B. 2011. Market Formation in Technological Innovation Systems -

4 Diffusion of Photovoltaic Applications in Germany. Industry and Innovation 18:285-300.

5 Dewald, U., and Fromhold-Eisebith, M. 2015. Trajectories of sustainability transitions in

6 scale-transcending innovation systems: The case of photovoltaics. Environmental Innovation

7 and Societal Transitions

8 DiMaggio, P. J., and Powell, W. W. 1983. The Iron Cage Revisited - Institutional

9 Isomorphism and Collective Rationality in Organizational Fields. American Sociological

10 Review 48:147-160.

Drori, I.; Honig, B.; and Wright, M. 2009. Transnational entrepreneurship: An emergent field of study. Entrepreneurship: Theory and Practice 33:1001-1022.

Essletzbichler, J., and Rigby, D. L. 2007. Exploring evolutionary economic geographies. Journal of Economic Geography 7:549-571.

15 Feldman, M. 2003. The locational dynamics of the US biotech industry: Knowledge externalities and the anchor hypothesis. Industry and Innovation 10:311-328.

Fligstein, N. 2007. The Sociology of Markets. Annual Review of Sociology 33:105-128.

Fligstein, N., and Zhang, J. 2011. A New Agenda for Research on the Trajectory of Chinese Capitalism. Management and Organization Review 7:39-62.

Florida, R., and Smith, D. F. 1993. Venture capital formation, investment, and regional 21 industrialization. Annals of the Association of American Geographers 83:434-451.

Foray, D. 2004. The economics of knowledge. Cambridge: MIT Press.

Frenken, K., and Boschma, R. A. 2007. A theoretical framework for evolutionary economic geography: Industrial dynamics and urban growth as a branching process. Journal of Economic Geography 7:635-649.

Frenken, K.; Van Oort, F.; and Verburg, T. 2007. Related variety, unrelated variety and regional economic growth. Regional Studies 41:685-697.

Fu, T.; Chang, M.; and Zhong, L. 2008. Reform of China's urban water sector. London: IWA 29 Publishing.

Gallagher, K. S. 2014. The Globalization of Clean Energy Technology - Lessons from China.

Garud, R.; Kumaraswamy, A.; and Karnøe, P. 2010. Path dependence or path creation? 
1 Gebauer, H.; Truffer, B.; Binz, C.; and Störmer, E. 2012. Capability perspective on business

2 network formation: Empirical evidence from the wastewater treatment industry. European

3 Business Review 190.

4 Geels, F. W. 2010. Ontologies, socio-technical transitions (to sustainability), and the multi-

5 level perspective. Research Policy 39:495-510.

6 Gilbert, B. A., and Campbell, J. T. 2015. The geographic origins of radical technological

7 paradigms: A configurational study. Research Policy 44:311-327.

8 Giuliani, E., and Rabellotti, R. 2012. Universities in emerging economies: Bridging local 9 industry with international science-evidence from Chile and South Africa. Cambridge Journal 10 of Economics 36:679-702.

11 Glaser, B. G., and Strauss, A. L. 1967. The discovery of grounded theory: Strategies for 12 qualitative research. New Brunswick, USA: Aldine Transaction.

Gosens, J., and Lu, Y. 2013. From lagging to leading? Technological innovation systems in emerging economies and the case of Chinese wind power. Energy Policy 60:234-250.

Gosens, J.; Lu, Y.; and Coenen, L. 2015. The role of transnational dimensions in emerging economy 'Technological Innovation Systems' for clean-tech. Journal of Cleaner Production 86:378-388.

Grabher, G. 2009. Yet another turn? The evolutionary project in economic geography. Economic Geography 85:119-127.

Grillitsch, M., and Trippl, M. 2013. Combining Knowledge from Different Sources, Channels and Geographical Scales. European Planning Studies

Gustafsson, R.; Jaaskelainen, M.; Maula, M.; and Uotila, J. in press. Emergence of Industries: A Review and Future Directions. International Journal of Management Reviews

Hassink, R.; Klaerding, C.; and Marques, P. 2014. Advancing Evolutionary Economic Geography by Engaged Pluralism. Regional Studies 48:1295-1307.

Hekkert, M.; Suurs, R.; Negro, S.; Kuhlmann, S.; and Smits, R. 2007. Functions of innovation systems: A new approach for analysing technological change. Technological Forecasting and Social Change 74:413-432.

Henning, M.; Stam, E.; and Wenting, R. 2013. Path Dependence Research in Regional Economic Development: Cacophony or Knowledge Accumulation? Regional Studies 47:1348-1362.

Hidalgo, C. A.; Winger, B.; Barabási, A. -.; and Hausmann, R. 2007. The product space conditions the development of nations. Science 317:482-487.

Jacobsson, S., and Bergek, A. 2011. Innovation system analyses and sustainability transitions: Contributions and suggestions for research. Environmental Innovation and Societal Transitions 1:41-57. 
Jiang, Y. 2009. China's water scarcity. Journal of Environmental Management 90:3185-3196.

Johnson, C., Dowd, T. J., and Ridgeway, C. L. 2006. Legitimacy as a social process. Annual Review of Sociology 32: 53-78.

Karnøe, P., and Garud, R. 2012. Path Creation: Co-creation of Heterogeneous Resources in the Emergence of the Danish Wind Turbine Cluster. European Planning Studies 20:733-752.

Kemp, R.; Schot, J.; and Hoogma, R. 1998. Regime Shifts to Sustainability Through Processes of Niche Formation: The Approach of Strategic Niche Management. Technology Analysis \& Strategic Management 10:175-195.

Klepper, S. 1996. Entry, Exit, Growth, and Innovation over the Product Life Cycle. American Economic Review 86:562-583.

Lee, S. 2006. Water and Development in China. The Political Economy of Shanghai Water Policy. Singapore: World Scientific Publishing.

Li, L.; Binz, C.; Lu, Y.; Truffer, B.; and Shi, Y. 2013. Institutional trajectory for diffusing onsite wastewater treatment in urban China. Water Science and Technology 68:1180-1187.

Lundvall, B.; Johnson, B.; Andersen, E. S.; and Dalum, B. 2002. National systems of production, innovation and competence building. Research Policy, 31:213-231.

MacKinnon, D.; Cumbers, A.; Pike, A.; Birch, K.; and McMaster, R. 2009. Evolution in economic geography: Institutions, political economy, and adaptation. Economic Geography 85:129-150.

Markard, J.; Wirth, S.; and Truffer, B. submitted. Institutional dynamics and technology legitimacy - A framework and a case study on biogas technology. Technological Forecasting and Social Change

Markard, J.; Raven, R.; and Truffer, B. 2012. Sustainability transitions: An emerging field of research and its prospects. Research Policy 41:955-967.

Markard, J., and Truffer, B. 2008. Technological innovation systems and the multi-level perspective: Towards an integrated framework. Research Policy 37:596-615.

Martin, R. 2012. (Re) Placing Path Dependence: A Response to the Debate. International Journal of Urban and Regional Research 36:179-192.

2011. Regional economies as path-dependent systems: some issues and implications. In Handbook of Regional Innovation and Growth, ed. P. Cooke, B. T. Asheim, R. Boschma, R. Martin, D. Schwartz and F. Tödtling, 198-210. Cheltenham: Edward Elgar.

— 2010. Roepke Lecture in Economic Geography—Rethinking Regional Path Dependence: Beyond Lock-in to Evolution. Economic Geography 86:1-27.

Martin, R., and Sunley, P. 2006. Path dependence and regional economic evolution. Journal of economic geography 6:395-437. 
1 Martin, R., and Moodysson, J. 2013. Comparing knowledge bases: On the geography and

2 organization of knowledge sourcing in the regional innovation system of Scania, Sweden.

3 European Urban and Regional Studies 20:170-187.

4 Maskell, P.; Bathelt, H.; and Malmberg, A. 2006. Building Global Knowledge Pipelines: The

5 Role of Temporary Clusters. European Planning Studies 14:997-1013.

6 Maskell, P., and Malmberg, A. 1999. The competitiveness of firms and regions.

7 'Ubiquitification' and the importance of localized learning. European Urban and Regional

8 Studies 6:9-25.

9 Mels, A.; Guo, S.; Zhang, C.; Li, X.; Wang, H.; Liu, S.; and Braadbaart, O. 2007.

10 Decentralised wastewater reclamation systems in Beijing - adoption and performance under

11 field conditions. First SWITCH Scientific Meeting University of Birmingham, UK, 9-10 Jan

122006.

13 Moulaert, F., and Sekia, F. 2003. Territorial Innovation models: A critical survey. Regional

14 Studies 37:289-302.

15 Musiolik, J., and Markard, J. 2011. Creating and shaping innovation systems: Formal 16 networks in the innovation system for stationary fuel cells in Germany. Energy Policy 17 39:1909-1922.

18 Musiolik, J.; Markard, J.; and Hekkert, M. 2012. Networks and network resources in 19 technological innovation systems: Towards a conceptual framework for system building.

20 Technological Forecasting and Social Change 79:1032-1048.

21 Nahm, J., and Steinfeld, E. S. 2014. Scale-up Nation: China's Specialization in Innovative 22 Manufacturing. World Development 54:288-300.

23 Neffke, F.; Henning, M.; and Boschma, R. 2011. How Do Regions Diversify over Time? 24 Industry Relatedness and the Development of New Growth Paths in Regions. Economic 25 Geography 87:237-265.

26 Nelson, R. R., and Winter, S. G. 1982. An Evolutionary Theory of Economic Change.

27 Cambridge, Massachusetts, and London, England: Belknap Press of Harvard University Press.

28 Oinas, P., and Malecki, E. J. 2002. The Evolution of Technologies in Time and Space: From 29 National and Regional to Spatial Innovation Systems. 25:102-131.

30 Pollard, J. S. 2003. Small firm finance and economic geography. Journal of Economic 31 Geography 3:429-452.

Quitzow, R. in print. Dynamics of a policy-driven market: The co-evolution of technological innovation systems for solar photovoltaics in China and Germany. Environmental Innovation and Societal Transitions

Saxenian, A. 2007. The new argonauts: Regional advantage in a Global Economy. Boston, 36 MA: Harvard University Press. 
Simmie, J. 2012a. Path Dependence and New Technological Path Creation in the Danish Wind Power Industry. European Planning Studies 20:753-772.

Simmie, J. 2012b. Path Dependence and New Path Creation in Renewable Energy Technologies. European Planning Studies 20:729-731.

Simmie, J.; Sternberg, R.; and Carpenter, J. in press. New technological path creation: evidence from the British and German wind energy industries. Journal of Evolutionary Economics

Sonderegger, P., and Täube, F. 2010. Cluster life cycle and diaspora effects: Evidence from the Indian IT cluster in Bangalore. Journal of International Management 16:383-397.

State Statistical Bureau of the People's Republic of China 1989. China Statistical Yearbook. Beijing: China Statistical Information and Consultancy Service Center.

Storper, M., and Walker, R. 1989. The capitalist imperative - Territory, Technology, and industrial Growth. New York: Basil Blackwell.

Strambach, S., and Halkier, H. 2013. Reconceptualizing change: Path dependency, path plasticity and knowledge combination. Zeitschrift fur Wirtschaftsgeographie 57:1-14.

Sunley, P. 2008. Relational economic geography: A partial understanding or a new paradigm? Economic Geography 84:1-26.

Suurs, R. A. A., and Hekkert, M. P. 2009. Cumulative causation in the formation of a technological innovation system: The case of biofuels in the Netherlands. Technological Forecasting and Social Change 76:1003-1020.

Sydow, J.; Windeler, A.; Müller-Seitz, G.; and Lange, K. 2012. Path Constitution Analysis: A Methodology for Understanding Path Dependence and Path Creation. BuR - Business Research, German Academic Association for Business Research (VHB) 5:155-176.

Tanner, A. N. 2014. Regional Branching Reconsidered: Emergence of the Fuel Cell Industry in European Regions. Economic Geography 90:403-427.

Trippl, M., and Tödtling, F. 2007. Developing biotechnology clusters in non-high technology regions - The case of Austria. Industry and Innovation 14:47-67.

Truffer, B.; Binz, C.; Gebauer, H.; and Störmer, E. 2012. Market success of on-site treatment: a systemic innovation problem. In Wastewater Treatment: Source Separation and Decentralisation, ed. T. Larsen, K. Udert and J. Lienert, 209-223. London: IWA Publishing.

Uyarra, E. 2009. What is evolutionary about 'regional systems of innovation'? Implications for regional policy. Journal of Evolutionary Economics 20:115-137.

Vale, M., and Carvalho, L. 2013. Knowledge networks and processes of anchoring in Portuguese biotechnology. Regional Studies 47:1018-1033. 
1 Wang, X.; Chen, R.; Zhang, Q. H.; and Li, K. 2008. Optimized plan of centralized and

2 decentralized wastewater reuse systems for housing development in the urban area of Xi'an,

3 China. Water Science \& Technology 58:969-975.

4 Witt, M. 2014. China: Authoritarian Capitalism. In The Oxford Handbook of Asian Business

5 Systems, ed. M. Witt and G. Redding, 11-33. New York, NY, USA: Oxford University Press.

6 Xin, K., and Pearce, J. 1996. Guanxi: Connections as substitutes for formal institutional

7 support. Academy of Management Journal 39:1641-1658.

8 Yeung, H. 2009. Transnationalizing entrepreneurship: A critical agenda for economic

9 geography. Progress in Human Geography 33:210-235.

10 Yin, R. K. 2009. Case study research: Design and methods. Thousand Oaks, CA: Sage. 4th 11 edition.

12 Zhang, S.Deng, L.Yue, P.; and Cui, H. 2007. Study on the water tariff reform and income 13 impacts in China's metropolitan areas: the case of Beijing. Peking University, Beijing:

14 College of Environmental Sciences and Engineering. 